\title{
Nanoparticles and microparticles of polymers and polysaccharides to administer fish vaccines
}

\author{
Andrea Rivas-Aravena, Ana María Sandino and Eugenio Spencer
}

Laboratorio de Virología, Centro de Biotecnología Acuícola, Universidad de Santiago de Chile.

\begin{abstract}
Aquaculture has become an important economic sector worldwide, but is faced with an ongoing threat from infectious diseases. Vaccination plays a critical role in protecting commercially raised fish from bacterial, viral and parasitic diseases. However, the production of effective vaccines is limited by the scarcity of knowledge about the immune system of fish. Improving vaccines implies using antigens, adjuvants and employing methods of administration that are more effective and less harmful to the fish. In this context, in recent year there have studies of methods of encapsulating antigens in matrices of different types to apply in fish vaccines. This work reviews the new methods to improve fish vaccines by encapsulating them in polymers and polysaccharides.
\end{abstract}

Key words: Nanoparticles, vaccine, aquaculture.

\section{INTRODUCTION}

The use of vaccinations is essential in aquacultural production in order to keep fish free of bacterial, viral and parasitic pathogens. This results in an ongoing need for research into new vaccines and especially new means of applying vaccines that are fish-friendly while at the same time strengthening the effect of the vaccination. However, until now vaccines have not been developed that provide efficient protection, especially to prevent viral, intracellular bacterial and parasitic infections (Hastein et al., 2005; Sommerset et al., 2005). Added to this, the great majority of vaccines are currently administered in water/ oil formulas that allow for an extended release of antigens (AG) while protecting them from degradation and inducing an inflammatory effect that strengthens the response of antibodies against the vaccine. However, despite the benefits that they can provide, adjuvants can cause adverse effects such as accumulation of myelin, adherence to tissue (Midtlyng 1997; Poppe \& Breck. 1997), deformation of the skeleton (Berg et al., 2006), granulomatous peritonitis, growth inhibition and increased mortality rates (Koppang et al., 2005; Evensen et al., 2005), as well as problems of autoimmunity (Koppang et al., 2008). Given the problems associated with the vaccines used in fish farming, it is critical to investigate and develop new vaccines, adjuvants and methods of release that are more efficient in protecting fish without producing negative effects.

In general, assessing vaccines involves measuring their effectiveness in stimulating immune response by evaluating antibodies in the blood of vaccinated fish. However, this humoral response often does not correspond to the level of protection provided by the vaccine (Cuesta et al., 2010; De Las Heras et al., 2010; Dorson et al., 1978; Gomez-Casado et al., 2011; Koellner y Kotterba 2002). The increased expression or the synthesis of some molecules associated with stimulating innate immune response in fish such as some inflammatory cytokines, interferon (IFN) and associated molecules is also currently used as a measure of the efficacy of vaccines (Walden et al., 1986; Walsh et al., 2003; Wang et al., 2011; Wang et al., 2005).

The above is not consistent with what has been found in recent studies about the design of vaccines for mammals sholwed the importance of allowing the antigen to interact efficiently with antigen-presenting cells (APC) to generate a favorable cellular and humoral immune response against the pathogen. Recognition and presentation by APC activates the specific and innate immune response of the individual. In higher mammals APCs include dendritic cells (DC), macrophages and B cells; their activation leads to presenting the antigen to immune system cells, activating the cellular response of lymphocyte helpers (Th), cytotoxic lymphocytes (CTL) and lymphocytes B. Phagocytized extracellular antigens are presented by membrane molecules called major histocompatibility complex class II (MHC class II) to Th lymphocytes, which leads to activation of lymphocytes B for the synthesis of specific antibodies against the antigen. The intracellular antigens that are not phagocytized are presented by MHC class I, which is recognized by CTL and is capable of lysing the infected cells. In this way, antigen recognition presented by APC through MHC I and II and the maturing of dendritic cells leads to the activation and orchestration of all levels of the immune response of the individual (Banchereau \& Steinman 1998; Banchereau et al., 2012). It has also recently been demonstrated that stimulating APC with inactivated phagocytized pathogens generates a cross-presentation of antigens by MHC I and II, triggering the immune response mediated by APC in all its levels (Brode \& Macary 2004; Joffre et al., 2012; Rodriguez-Pinto 2005; Wetzel \& Parker 2006). This is important for the use of vaccines based on inactivated pathogens and others that are not endogenous antigens of the APCs (Pooley et al., 2001; Sigal et al., 1999).

There are several reports of characterization of macrophages and DC presenters of antigens in fish with phagocytic activity and production of proinflammatory cytokines (Bassity y Clark 2012; Haugland et al., 2012; Lugo- 
Villarino et al., 2010; Pettersen et al., 2008; Vallejo et al., 1992). It has also been determined that B cells in fish have phagocytic activity (Li et al., 2006), which, as has been shown recently in mammals, can strengthen APC activity (Parra et al., 2012).

Vaccines are administered to fish by intraperitoneal or intramuscular injection. While injection allows for the use of smaller and precisely known doses of AG and confers protection for longer periods of time, the technique requires more manipulation of the fish and the use of anesthesia, which causes stress and greater harm to the fish, along with high costs for the producer. Consequently, under field conditions fish weighing over $20 \mathrm{~g}$ are vaccinated while smaller fish, which are more vulnerable because they have not yet fully developed their immune system, are left unprotected. Laboratorios Centrovet Ltd. in Chile is the only company that has developed oral vaccines encapsulated in MicroMatrix ${ }^{\circledR}$ (licensed under Advance BioNutrition Corp), which have had good results against salmonid rickettsial septicemia (SRS) and Infectious salmon anemia virus (ISAV). Several studies have shown that the administration of antigens or immunostimulants orally or by immersion can stimulate the immune response associated with the intestine of the fish (Quentel \& Vigneulle 1997; Rombout et al., 2006). In fish, as in higher vertebrates, there is very complex mucosaassociated lymphoid tissue (MALT) in the gut (GALT), skin (SALT) and gills (GIALT), with a specific and specialized immune response for these tissues, with different immune cells and antibodies from those found in the blood (Tyagi et al., 2012). The efficiency of this response depends on the immunization route, given that oral and anal administration in fish activates GALT, which presents greater efficiency in some species. Immersion activates SALT and GIALT, while injection generally does not activate any of these (Salinas et al., 2011; Joosten et al., 1997; Rombout et al., 1989). Parallel to this, it has been shown that the enterocytes in the hindgut are capable of transporting antigens and that in the lamellae and epithelial cells there are populations of macrophages and lymphoid cells that can participate in presenting antigens in the intestine of the fish (Doggett \& Harris 1991; Georgopoulou \& Vernier 1986; Rombout et al., 2006). All of this indicates that the administration of the vaccine orally or by immersion stimulates a different response from that stimulated by intraperitoneal or intramuscular administration, one that is similar to the response to the pathogen.

All of the above indicates that to obtain a good vaccine it is critical to use antigens and adjuvants that stimulate the appropriate immune response and that permit forms of delivery of the antigen that are not harmful to the fish. Consequently, in aquaculture, as in other forms of animal production, alternative systems of administering antigens are being explored that strengthen the vaccine, such as encapsulation of molecules in polymeric and polysaccharide particles.

Microparticles (MP, size in $\mu \mathrm{m}$ ) and nanoparticles (NP, size in $\mathrm{nm}$ ) have emerged as efficient and safe methods to deliver drugs and antigens to animals (Toyokawa et al., 2008). In fact, at present particles that encapsulate different types of molecules are administered to humans (Food and Drug Administration, FAO; Lu et al., 2009). Polymeric and polysaccharide particles can be designed to be administered by different means, such as orally or by injection or inhaling, and to encapsulate different types of molecules (Morachis et al., 2012). They can also be directed to specific sites of interest in the organism while protecting them from biological degradation (Morachis et al., 2012). The direct benefit of encapsulation in particles is that it permits reducing the doses of medication, making its delivery to specific tissue and avoiding or reducing the toxic effects or secondary effects of the drug, making the delivery of the drug more efficient and less expensive (Toyokawa et al., 2008). The small size of nanoparticles makes it possible to spread them throughout the organism through the circulatory system, including the capillaries, finally entering the target cells. Larger microparticles can release antigens in the place of administration (circulatory system, gastrointestinal tract), allowing the synthesis of antibodies against the antigen and a general inflammatory response (Tafaghodi et al., 2007).

The particles used to deliver molecules to living organisms are biodegradable and non-toxic and can be designed to be highly versatile in terms of their size, physical-chemical properties and the release of antigens; it is possible to modify them for the efficient delivery of any type of molecule in specific organs, tissues or cells. For example, nanoparticles can be designed to change the physical-chemical properties of the drug that is being administered, increasing its solubility, decreasing its elimination time, improving its renal excretion or varying the selection and mechanism of incorporation in cells or its distribution in the organism (Doshi et al., 2010; Morachis et al., 2012). The polymers are also versatile in their facility to join with antibodies and other molecules that interact with cellular receptors, such as DNA aptamers (Morachis et al., 2012).

Many polymeric and polysaccharide particles have adjuvant capabilities because they protect the encapsulated molecule from biological degradation, stimulating the immune response against the antigen (Broos et al., 2010; Clawson et al., 2010). This form of delivery also allows the antigen to reach the necessary organs and tissues to stimulate an efficient immune response, which is difficult with soluble antigens regardless of the method of administration. A nanoparticle can be the same size as a pathogen and can be easily incorporated by the APC, stimulating the immune response (Audran et al., 2003; Diwan et al., 2003; Elamanchili et al., 2007; Fischer et al., 2009). It has been reported that nanoparticles are mainly endocyted while microparticles are mainly phagocyted (Burgdorf \& Kurts 2008). Other reports indicate that APCs easily phagocyte nano and microparticles (between $150 \mathrm{~nm}$ to $4.5 \mu \mathrm{m}$, (He et al., 2010; Thiele et al., 2001), the optimal size for phagocytosis being $500 \mathrm{~nm}$ (Burgdorf \& Kurts 2008). It has also been shown that microparticles have more affinity for peripheral dendritic cells, while nanoparticles prefer dendritic cells lodged in lymphatic nodes (Manolova et al., 2008; Reddy et al., 2006). It has also been shown that microparticles of less than $10 \mu \mathrm{m}$ are incorporated into the intestine, nanoparticles of more than $100 \mathrm{~nm}$ are incorporated in monocytes and those of less than $100 \mathrm{~nm}$ can be incorporated in non-phagocytic cells (Agnihotri et al., 2004; Desai et al., 1997). In this manner, nanoparticles that encapsulate antigens can resemble pathogens in terms of the means of administration, mirroring the route of pathogen entry and the immune response that is triggered (Gutierro et al., 2002). The particles may also have antigens on their surface, which is a good stimulant for the B cells (Fehr et al., 1998; He et al., 2005).

Methods are now being developed in aquaculture to encapsulate antigens for their efficient and harmless 
application while strengthening the effect of nano- or microparticle vaccines. The first tests of encapsulating antigens against Vibrio anguillarum in fish through the use of prills, acid resistant coating, dextrose and resistant films did not stimulate antibody production or result in better protection than that offered by inactivated naked bacteria (Lillehaug 1989; Wong 1992). Nevertheless, new technologies of encapsulation of antigens for fish have been implemented, such as those employing polymers and polysaccharides.

\section{METHODS OF ANTIGEN ENCAPSULATION}

Alginate

Alginate is a copolymer of $\beta$-D- mannuronic acid (M) and $\alpha$-L-guluronic acid $(G)$ that is found in the cell wall of brown algae. Alginate has been used widely in encapsulation of antigens for several reasons: its low level of toxicity (Lim \& Sun 1980); its mucoadhesiveness allows contact of the alginate particle with the walls of the epithelial mucus (Wee y Gombotz 1998); it is resistant to acidic conditions and to proteases; and it is inexpensive (Bowersock et al., 1999). The characteristics of the alginate particle are a result of its size, antigenic composition, the strategy in its production, the choice of alginate and the antigen concentration. For example, the production of microparticles from alginate is generally done by emulsification/gelation, where the alginate emulsion in the presence of the molecule to be encapsulated reacts with calcium ions that promote the piling of G. In this technique, the specifications of the protocol, that is, the viscosity, molecular weight and the concentration of the alginate, stirring times, temperature, gelation agent, the arrangement of its monomers (MM, GG and MG form), type of surfactant, among others, markedly influence the physical-chemical characteristics obtained (Lemoine et al., 1998; Rodrigues et al., 2006). Similarly, molecules are mainly released by diffusion or erosion of the microparticle, which depends on the molecular size of the active agent and the concentration of the alginate, as well as the external environment (Tanaka et al., 1984).

Notably, there have been several reports indicating that alginate can act as an antigen adjuvant (Borges et al., 2008; Tafaghodi et al., 2007). Administered alone or as a complement, alginate is capable of increasing the survival and weight of fish (Fujiki et al., 1994; Yeh et al., 2008). The administration of alginate has been shown to stimulate the immune response of carp (Cyprinus carpio L.) and the brownmarbled grouper (Epinephelus fuscoguttatus, Cheng et al., 2008; Huttenhuis et al., 2006; Yeh et al., 2008) and increases the protection of the turbot (Scophthalmus maximus L.) against $V$. anguillarum (Skjermo \& Berghb 2004; Skjermo et al., 1995), and the orange-spotted grouper (Epinephelus coioides) and brownmarbled grouper against iridovirus and Streptococcus sp. (Cheng et al., 2008; Yeh et al., 2008).

One of the characteristics of alginate microparticles that makes them useful for delivering drugs is their resistance to acid $\mathrm{pH}$, which impedes the release of the antigen in the stomach of the fish $(\mathrm{pH} \mathrm{2-4)}$ and favors their its release in the foregut or hindgut ( $\mathrm{pH} 7$ and 8.3, respectively) (Joosten et al., 1997; Leal et al., 2010; Rodrigues et al., 2006; Salinas et al., 2011). Microparticles from 10 to $50 \mu \mathrm{m}$ can be efficient for vaccinating, although it has been shown that the smaller the size, the greater the efficiency of incorporation (Rodrigues et al., 2006; Romalde et al., 2004). There are reports of administering antigens and molecules to fish enveloped in alginate with microparticles of 1 to $50 \mathrm{~mm}$, as will be described in detail below.

\section{Bacterial antigens encapsulated in alginate}

There have been several studies of the use in aquaculture of bacterin encapsulated in alginate. The results vary with the fish species, method of delivery and use of a booster, but in general they are not related with stimulation of fish antibodies. In fact, the oral administration of microparticles of Flavobacterium to Nile tilapia (Oreochromis niloticus) did not stimulate the production of antibodies in serum, but intraperitoneal and intramuscular administration did. This stimulation does not correlate with protection against infection with any of the studied vaccines (Leal et al., 2010). However, better results were obtained when bacterin microparticles were used as an oral booster after intraperitoneal vaccination with naked bacterin, reaching $87 \%$ relative survival (RPS) (Altun et al., 2010; Romalde et al., 2004). Oral administration to goldfish (Carassius auratus) of alginate microparticles of the protein A of Aeromona salmonicida, alone or fused with membrane translocation sequences (MTS) derived from Kaposi fibroblast growth factor, stimulated antibodies in serum a month after administration for three days to a week, and after two months when it was administered for five days to a month, which correlated with the presence of protein $\mathrm{A}$ in the serum of vaccinated fish There was greater stimulation of antibodies in serum with the intraperitoneal administration of a booster two weeks after the oral administration of the vaccine. Despite the increase in antibodies, all the vaccinations caused only a slight decrease in the symptoms among the infected fish (Maurice et al., 2004)

The oral and intraperitoneal administration of Lactococcus garvieae microparticles to rainbow trout (Oncorhynchus mykiss) protected against infection, reaching a relative survival of $50 \%$, which was less than the survival rate obtained with naked bacterin applied intraperitoneally (83.3\% RPS) (Altun et al., 2010; Romalde et al., 2004). This is consistent with the fact that in general vaccines against gram positive pathogens lactococci and Streptococcus iniae are only effective when administered intraperitoneally, although the efficacy is for short periods (2-3 months, Eldar et al., 1997; Romalde et al., 1999).

The different means of administering vaccines stimulate different types of immune response in carp (Cyprinus carpio), similar to what occurs in mammals. Microparticles of bacteria such as Vibrio Anguillarum administered orally increase the number of antibodies in the mucus of the gut and gills and very little in serum. In contrast, antibodies increased in serum, head kidney, blood, but not in the gut and gills in carp vaccinated and challenged intramuscularly (Joosten et al., 1997). Although in the case of carp the vaccination with microparticles is capable alone of increasing the number of antibodies in serum, with rainbow trout a booster is required to do the same. This is probably due to the difference in swelling and antigen release from alginate microparticles at different $\mathrm{pH}$ levels, resulting in the microparticles not releasing antigens in the stomach but rather in the intestine. Unlike the rainbow trout, the carp does not have a stomach, so that antigens are released sooner and likewise stimulate an immune response more rapidly. In fact, antigens are found carp enterocytes 16 hours after administering the 
vaccine, while they are found in the enterocytes of rainbow trout 24 hours after administration. Finally, the response of immunoreactive macrophages is only found at 36 hours postadministration (Joosten et al., 1997).

Viral antigens encapsulated in alginate

Vaccinations with alginate microparticles against virus have used DNA vaccines that code for immunogenic viral protein. Encapsulation has resulted in obtaining microparticles smaller than those of bacteria (10 um), which allows for their incorporation and DNA expression in organs such as spleen, kidney, liver, pyloric caeca and stomach for months after the vaccination by depositing microparticles in the stomach using stents (De Las Heras et al., 2010; Tian et al., 2008). The period of protection is much longer than administration of naked DNA is administered (Tian et al., 2008; Zheng et al., 2006).

The oral vaccination of Japanese flounder (Paralichthys olivaceus) with microparticles of DNA that encodes for a fragment of the protein of the capsid the lynphocystis disease virus (LCDV) (Zheng et al., 2006) protected against viral disease and produced a sustained increase in specific antibodies against LCDV in serum for up to 14 weeks, at which point it began to decline owing to the degradation of the DNA. In contrast, fish vaccinated with naked DNA did not produce antibodies, which suggests that the alginate particles that enter the blood are distributed to immune tissue and stimulate immune response for longer periods than does naked DNA (Tian et al., 2008).

The oral vaccination of rainbow and brown trout (Salmo trutta) with microparticles of DNA of the VP2 protein of the infectious pancreatic necrosis virus (IPNV) stimulated the IFN and $\mathrm{Mx}$ at 7 and 5 days post-vaccination (dpv), respectively, and increased neutralizing antibodies against IPNV during the eight weeks of evaluation, peaking at three weeks. In this case, the protection against IPNV infection was high, with a $15 \%$ mortality rate for brown trout and $15-20 \%$ for rainbow trout. Moreover, the unvaccinated fish that survived the infection present the virus circulating, which can be isolated with high titers in a first passage in BF-2 cells, while the IPNV titers obtained from the surviving fish that were vaccinated with microparticles were 1 to 7 orders of magnitude lower and were obtained in the second passage with BF-2 cells, showing that there is less risk that vaccinated carriers will spread the disease than unvaccinated carriers (De Las Heras et al., 2010).

These studies have shown that the oral administration of bacterins encapsulated in alginate provides the same or less protection than that provided by intraperitoneal administration of naked bacterins and that the vaccination of viral DNA encapsulated in alginate provides protection against viral diseases. Consequently, encapsulation with alginate is promising in terms of providing protection against viral and bacterial pathogens in aquaculture.

\section{Chitosan}

Chitosan is a linear polysaccharide compound of $\beta$-(1-4)-linked $\mathrm{D}$-glucosamine and $\mathrm{N}$-acetyl-D-glucosamine that is derived from the deacetylation of chitin, which is found in the exoskeletons of crustaceans, insects and some microorganisms. Deacetylation changes the chain conformation and electrostatic properties of chitin, increasing its solubility and leaving amine-reactive groups in its ends, from which derivatives can be obtained with specific characteristics by adding different molecules at the ends. Antimicrobial, anti-inflammatory, hemostatic and antiviral properties have been attributed to chitosan. It has also been attributed to inhibit tumors, regenerate tissue, heal injuries and to be an immunostimulant. Chitosan is mucoadhesive and increases transcellular transport in intestinal cells (Davis 2006; Ghendon et al., 2008; Ouji et al., 2002).

Chitosan has adjuvant characteristics similar to those of Freund's incomplete adjuvant and better than those of aluminum hydroxide in terms of its capacity to increase the protection offered by vaccines for mammals (Coeshott et al., 2004; Ghendon et al., 2008; Zaharoff et al., 2007). In fact, chitosan stimulates the synthesis of cytokines and activates immune cells such as macrophages, natural killer cells (NK), APC cells and T lymphocytes (Foged et al., 2005; Nagamoto et al., 2004; Nishimura et al., 1984; Peluso et al., 1994; Porporatto et al., 2005; Koppolu \& Zaharoff 2013).

Chitosan particles have highly variable characteristics depending on their purity, molecular weight, degree of deacetylation, quality and viscosity. Also, a variety of particle sizes can be obtained (Koppolu \& Zaharoff 2013). In general, low molecular weights of chitosan $\left(1.5^{*} 10^{5}\right)$ produce stronger capsules. The release of encapsulated content depends on the diffusion among the pores and the chitosan charge, given that acid molecules are more permeable. The size of the particle is related to the type of incorporation into the organism (Agnihotri et al., 2004).

The beneficial effects on fish of chitosan have been demonstrated. Diets supplemented with $0.25 \mathrm{~g}$ of chitosan/ $\mathrm{Kg}$ for rainbow trout improve resistance to environmental stress and hematological parameters, resulting in higher levels of lymphocytes and decreased levels of neutrophils and eosinophils (Meshkini et al., 2012). It has also been demonstrated that the DNA of $\beta$-galactosidase encapsulated in chitosan leads to significantly greater expression of the enzyme in the spleen, stomach and gills in Tilapia when the vaccine is administered orally than by injection (Ramos et al., 2005).

DNA fish vaccines encapsulated in chitosan are viable and stable because DNA is easily incorporated into chitosan, given its positive charge. The microparticles protect the encapsulated DNA from degradation by DNase (Rajesh Kumar et al., 2008) and from shear forces (Tian et al., 2008). Notably, the DNA vaccine can transfect fish cells and present very low levels of cytotoxicity (Rajesh Kumar et al., 2008). Thanks to these characteristics, chitosans can be used to administer DNA and vaccines of diverse natures to fish orally or by injection. These characteristics have led to studying the application of chitosans in the context of developing vaccines for fish.

Bacterin antigens encapsulated in chitosan

The DNA that encodes for the protein of the external membrane of $38 \mathrm{kDa}$ (OMP38) of Vibrio anguillarum was encapsulated in chitosan and administered with feed to Asian sea bass (Lates calcarifer). The viral protein was detected in gills, spleen, liver and intestines. Three weeks after the vaccination, there was a low level of stimulation of antibodies of the fish. The protection against Vibrio anguillarum caused a 46\% RPS (Rajesh Kumar et al., 2008). Also, when chitosan/ alginate microparticles were used to encapsulate Vibrio anguillarum or BSA (bovine serum albumine) it was found 
that more antigen is released with lower molecular weight of chitosan and that as with alginate, there is more antigen release in a basic $(\mathrm{pH} 9)$ rather than an acid environment $(\mathrm{pH}$ 3, Polk et al., 1994).

Viral antigens encapsulated in chitosan

Encapsulating the DNA of a fragment of the protein of the LCDV capsid (Zheng et al., 2006) produces microparticles of the same size $(10 \mu \mathrm{m})$ as those of alginate using a similar strategy to water/oil emulsion (Tian et al., 2008) and with stability levels comparable to those of microparticles of alginate in the acids of the stomach and the intestine $(\mathrm{pH}=2$ and 9, respectively). Following the administration to rainbow trout by stomach intubation, the expression of the protein fused to GFP was detected in gills, intestine, spleen and kidney for 90 days, and was less intense than when alginate microparticles were used (Tian et al., 2008). Antibodies were stimulated to the same magnitude as with alginate microparticles (Tian et al., 2008), but with a maximum in week four and a slow decline to week 16 without reaching the level of the negative control, indicating that there is a prolonged synthesis of antibodies against LCDV in vaccinated fish (Tian et al., 2008).

Despite the apparent advantages offered by chitosan, there have not been sufficient studies on the effectiveness of encapsulating antigens with chitosan.

Liposomes

Liposomes are vesicles of phospholipids that form spontaneously in aqueous solutions and are capable of trapping dissolved particles in such solutions. They are biodegradable, liberating the charged molecule slowly when they degrade in the organism. Liopsomes can have different characteristics depending on their size, the number of lamellae that make them up and the capacity to trap molecules in solution (Gregodiaris 1990 ).

Liposomes have good immunogenic capacity and have been approved for use as adjuvants with humans. It is argued that their rapid incorporation in APCs in the injection site permits them to act as a good adjuvant, activating the cellular response. Their versatility allows for encapsulating molecules of different characteristics and of different types (Gregodiaris 1990; Gregoriadis et al., 2002; Mbow et al., 2010).

Beneficial effects have been determined from administering liposomes derived from lecithin egg yolks as a food supplement for larvae of gilthead seabream (Sparus aurata) and white grouper (Epinephelus aeneus) (Koven et al., 1999). Liposomes have been used in different types of research related to fish farming. Clodronate liposomes have been used to investigate macrophage activity in rainbow trout (Espenes et al., 1997) and phosphatidylcholine liposomes have been used successfully to transfect African carp embryos by incubating the embryo with the liposome at room temperature, achieving high levels of efficiency in transfecting the DNA that encodes for neomycin (92\%, Szelei et al., 1994).

The liposome charge needs to be considered when administering molecules to fish in liposome, given that fish gills contain a high level of mucin. The sialic acid of the mucin is deprotonated by the $\mathrm{pH}$ of the water (Lumsden \& Ferguson 1994), facilitating its interaction with cationic liposomes of
$<100$ nm that encapsulate DNA, for example, increasing the residence time and the uptake of the load. This interaction results in high concentrations of cationic liposomes that are fatal for fish, presumably because the interaction with the gills can provoke hypoxia in the fish. In contrast, similar concentrations of anionic or neutral liposomes are not fatal (Romoren et al., 2002).

Fernández-Alonso et al. (1999) showed that liposomes could allow for DNA expression when they are administered to fish. The immersion of rainbow trout in 10-20 $\mu \mathrm{m}$ of DOTAP liposomes containing codifying DNA for green fluorescent protein (GFP) resulted in detecting GFP in the fins of $0.2-0.5$-gram fish, suggesting that vaccination by immersion is feasible for small fish (Fernandez-Alonso et al., 1999). They also demonstrated that the encapsulation in DOTAP of the DNA that encodes for GFP expresses the protein in the caudal fin of rainbow trout at a similar level to that when the fish are exposed to short ultrasound pulses in the immersion bath of naked DNA (Fernandez-Alonso et al., 2001). Studies have indicated that there is no direct relationship between the size of the liposomes and the specific organs in which they accumulate, but there is a relationship in terms of their capacity to lodge in certain organs. When large unilamellar phosphatidylcholine (PC) liposomes (LUV, $250 \mathrm{~nm}$ ) were administered interperitoneally to rainbow trout they accumulated in greater proportions in organs than did multillamellar liposomes (MLV, 1-5 $\mu \mathrm{m})$. At 24 hours after administration, they had accumulated (in decreasing order) in the spleen, head kidney, posterior kidney, visceral fat and liver, and were almost indistinguishable in gills, heart and muscles (Power et al., 1990). The accumulation of liposomes in hematopoietic organs has also been documented by (Nakhla et al., 1994). Liposomes are easily degraded in the stomach, so that studies of vaccinations of fish with liposomes involve administration by IP injection or immersion.

Bacterin antigens encapsulated in liposomes

Phosphatidylcholine liposomes, which encapsulate a mixture of inactivated Aeromona salmonicida with formaline, together with LPS and inactivated toxin were administered by immersion to rainbow trout and provided limited protection against furunculosis, being slightly more efficient than the free antigen (Rodgers 1990). Intraperitoneal vaccination with LPS in MLV and LUV liposomes followed by the booster with LPS had more effect in stimulating antibodies and for a longer period of time than the vaccination and booster with LPS. Antibody stimulation was greater depending on the number of immunizations, without showing significant differences when using different charge of phospholipids (Nakhla et al., 1997)

\section{Viral antigens encapsulated in liposomes}

The administration by immersion of particles of DOTAP of the DNA that encodes for the G protein of VHSV allows for a similar expression in the caudal fin of rainbow trout as when the particles are administered by short ultrasound pulses in the immersion bath of naked DNA, resulting in an increase in the number of antibodies of a lower magnitude than when administered by ultrasound or IP. However, this expression of DNA does not offer protection from VHSV infection, 
while ultrasound and IP administration do offer protection (Fernandez-Alonso et al., 2001)

More research is needed into liposomes of different types to determine their utility in the encapsulation of antigens for fish. Modified liposomes that are resistant to digestion in the stomach make it possible to use oral vaccines.

\section{Poly (D,L-lactic-co-glycolic) acid (PLGA)}

PLGA is a poly(lactic acid) (PLA) and poly(glycolic acid) (PGA) that can be designed in different sizes and shapes and can be used to encapsulate many types of molecules. PLGA is easily degraded in the organism, since in an aqueous environment its ester bond is hydrolyzed, which allows for the easy release of antigens. The velocity of hydrolysis in water is variable and depends on the PLA/PGA ratio of the polymer, but it is higher in acid environments. Unlike PGA, PLA contains a methyl group, and at higher proportion of PLA the copolymer is more hydrophobic, slower the hidrozylation. Similarly, the PGA/PLA ratio influences other physicalchemical parameters of the particles such as mechanical force, hydration capacity (swelling behavior), gelation temperature, charge, etc. PLGA has a negative charge.

PLGA particles show great flexibility in the encapsulation of different molecules (Elamanchili et al., 2007; Tamber et al., 2005) and have been used to administer vaccines to humans and other mammals (Lu et al., 2009). PLGA particles can act as adjuvants (Diwan et al., 2004; Katare \& Panda 2006) and their use for humans and in veterinary medicine has been accepted by the FDA. It has been demonstrated that PLGA microparticles generally promote a humoral response, while PLGA nanoparticles trigger a cellular response (Chong et al., 2005; Gutierro et al., 2002; Harding \& Song 1994).

PGLA particles allow for the co-release of multiple antigens and are capable of transporting antigens to intracellular compartments. As they are less hydrophilic than alginate particles, they are easily incorporated into the cell. They can be designed to be same size as the pathogens to stimulate APC (Broos et al., 2010; Diwan et al., 2004; Gupta et al., 1997; Hamdy et al., 2007; Johansen et al., 1998; Katare et al., 2005; Norton et al., 2010; Schlosser et al., 2008). Also, depending on their characteristics, their biological degradation can take months to years (Prokop \& Davidson 2008; Vert et al., 1994).

In general, PLGA encapsulating particles are obtained by water/oil/water emulsion in which the PLGA is dissolved in an organic solvent such as chloroform, dichloromethane or ethyl acetate and is emulsified with an aqueous solution of AG in the presence of a surfacant that is emulsified again in an aqueous solution, generally of polyvinyl alcohol. The method of obtaining the copolymers, their size and composition are critical characteristics required of PLGA particles. During the protocol, sonication results in nanoparticles of $\pm 100 \mu \mathrm{m}$, homogenization results in particles of $\pm 1 \mu \mathrm{m}$, and vortexing/ stirring in particles of $\pm 10 \mu \mathrm{m}$. Also, copolymers rich in PLA are more stable to hydrolysis (Desai et al., 1996).

PLGA nanoparticles can be modified according to the characteristics that it is desired to strengthen. For example, PLGA nanoparticles can generally resist the environment of the gastrointestinal tract when administered orally ( $\mathrm{Li}$ et al., 2008; Pandey \& Khuller 2007; Shaikh et al., 2009). Nevertheless, to increase the stability in acid environments a strategy has been developed of polyethylene glycol coating
(PEG, Garinot et al., 2007) that decreases interaction with the environment and offers protection from the medium and macrophages (Owens \& Peppas 2006). The particles are also coated with the anionic polymer Eudragit L30D, which impedes hydrolysis in acid $\mathrm{pH}$ but does permit hydrolysis in basic pH (Naha et al., 2008). Once inside the cell the PLGA nanoparticles can escape from endosomes (Panyam et al., 2002), facilitating the presentation of antigens encapsulated by cross-presentation pathway (Shen et al., 2006). PLGA nano and macroparticles may also be conjugated with proteins, antibodies or aptamers that allow selecting particles by specific cell types (Singh / Srivastava 2003).

In mammals PLGA nanoparticles accumulate rapidly in the liver, bone marrow, lymphatic nodes, spleen and peritoneal macrophages (Makadia \& Siegel 2011). Notably, when PLGA nanoparticles are administered orally in mammals they can increase the immune response associated with mucosal membrane (Danhier et al., 2012). They can also be phagocytized by APC much more easily than soluble antigens, thus imitating the nature of the pathogens. In fact, PLGA nanoparticles have been used to incorporate antigens into human dendritic cells, demonstrating that PLGA nanoparticles cause a significant increase in CTL activity (Ma et al., 2012), Th activity, the expression of regulatory cytokines and the maturation of dendritic cells. Notably, PLGA nanoparticles can activate dendritic cells in the absence of antigen, stimulating the expression of cytokines, immune cells and co-stimulatory molecules (Clawson et al., 2010; Cruz et al., 2011; Diwan et al., 2003; Elamanchili et al., 2004; Goforth et al., 2009; Gutierro et al., 2002; Hamdy et al., 2011; Lutsiak et al., 2002; Manolova et al., 2008). These characteristics of PLGA significantly increase the immunogenic capacities of encapsulated antigens.

After incubating different-sized PLGA particles with the TO leukocyte line of Atlantic salmon (Salmo salar), nanoparticles are incorporated more than microparticles in cellular cytoplasm (Fredriksen \& Grip 2012). Also, using media that simulate the environment of the fish gastrointestine, it has been shown that the release of DNA is more rapid with large-sized PLGA nanoparticles. For nanoparticles of $<100 \mathrm{~nm}$, less than $10 \%$ of DNA is released in a medium that simulates the gastric fluid and less than $6.5 \%$ in medium that simulates intestinal fluid in the first 12 hours (Tian et al., 2008), while the release of DNA from nanoparticles of $<330 \mathrm{~nm}$ is rapid, $100 \%$ in $60 \mathrm{~h}$ at $\mathrm{pH}$ 2, and in $90 \mathrm{~h}$ at $\mathrm{pH} 9$ (Tian \& Yu 2011).

PLGA particles can be administered orally to fish. Being hydrophobic, PLGA particles swell when exposed to solutions, which occurs mostly in acids, allowing for the release of the molecular load. Experimenting with different PLG: PLA ratios, found that the ratio 75:25 stabilized the nanoparticles and slowed their degradation in the gastrointestinal tract (Fredriksen \& Grip 2012).

PLGA microparticles are capable of protecting antigens, increasing the retention time in the stomach and slowing down the passage to the intestine of the Atlantic salmon (Lavelle et al., 1997), allowing antigens to remain for extended periods in sera and organs (O'donnell et al., 1996). Other studies have shown that 550-nm PLGA nanoparticles encapsulating coumarin- 6 accumulate more in the hindgut than the foregut (Adomako et al., 2012).

It has been shown that nano- and microparticles of PLGA encapsulating AG administered by intraperitoneal injection have the adjuvant capacity to stimulate the expression of pro- 
inflammatory cytokines and antibodies in a similar manner to that of oily adjuvants in rohu (Labeo rohita) and Atlantic salmon (Behera et al., 2010; Fredriksen \& Grip 2012; Fredriksen et al., 2011). The immune response is stimulated in Atlantic salmon within two days after intraperitoneal administration of PLGA nanoparticles of $\beta$-glucan. Administering $\beta$-glucan and an adjuvant in nanoparticles generates an inflammatory response in the spleen and kidneys, similar to or greater than that provoked by oily adjuvants at two days posttreatment. It is notable that the response, although in a lesser magnitude, is obtained when the nanoparticles are used alone. The response is more pronounced in the spleen, where the nanoparticles are reported to accumulate (Fredriksen et al., 2011). Respiratory burst activity (RB), myeloperoxidase activity and other immune parameters were also higher with the use of nanoparticles than with the use of oily adjuvants (Behera et al., 2010), and the response of antibodies was similar to that of oily adjuvants (Behera et al., 2010; Fredriksen \& Grip 2012). By 60 and 75 days after administration the nano- and microparticles of gamma globulin from human blood and $\beta$-glucan stimulated high levels of antibodies, up to 90 and 120 days, respectively. This response is less prolonged when the antigen is administered in an oily adjuvant (Fredriksen y Grip 2012). The size of the PLGA particles markedly affects where they will accumulate. PGLA microparticles $(8.1 \mu \mathrm{m})$ and the formulation of oily adjuvant form deposits in the injection site and adjacent organs, while PLGA nanoparticles $(<1000 \mathrm{~nm})$ accumulate primarily in the kidneys. This suggests that microparticles release antigens locally in the injection site, while nanoparticles associate with macrophages that can phagocyte them to present antigens (Fredriksen y Grip 2012). The intrabuccal administration of human gamma globulin (HGG) PLGA stimulates antibodies in serum but not in cutaneous or intestinal mucous or in bile (Lavelle et al., 1997).

PLGA has been among the most versatile polymers for encapsulation in terms of allowing for modifications and improvements that have been tested in mammals. In relation to vaccinating fish, PLGA has been the most extensively studied method of encapsulating antigens, with the successful application of nano- and microparticle vaccines that have offered effective protection against pathogens, as will be described below.

Bacterial antigens encapsulated in PLGA

In general, bacterin encapsulation in PLGA has yielded good results when administered intraperitoneally. The bacterin of Lactococus garvieae encapsulated in PLGA and administered orally provided the same magnitude of protection to rainbow trout as that encapsulated in alginate $(62.79 \%$ RPS) and to a lesser degree than bacterin administered by IP (95.34\% RPS) when the challenge was presented at 30 days post-vaccination. However, when the vaccinated fish received a booster with PLGA or alginate with bacterin, the survival rate was double that of fish that did not receive the booster (Altun et al., 2010).

Recombinant outer membrane protein (OMP) of Aeromonas hydrophyla encapsulated in 1.121- $\mu \mathrm{m}$ microparticles of PLGA can induce an innate immune and antibody response in rohu when administered intraperitoneally (Behera et al., 2010).

It has been shown that injecting oligodeoxyribonucleotides with $\mathrm{CpG}$ motifs (CpG ODN) stimulates immune parameters that can provide protection against diseases (Carrington \&
Secombes 2007; Martinez-Alonso et al., 2011; Nakatani et al., 2007; Pridgeon et al., 2012). CpG-ODN was encapsulated in PLGA/polysomal nanoparticles to be administered intraperitoneally to kelp groupers twice in a period of a week. PLGA, liposomes, and ODN PLGA/liposomes were able to stimulate $\mathrm{RB}$, superoxide dismutase (SOD), complement and antibodies, the PLGA/liposome mixture causing the greatest effect. These intraperitoneal vaccinations decreased the mortality rate by Vibrio alginolyticus from $90 \%$ to 20,15 and $15 \%$, respectively. Injection with naked ODN decreased mortality caused by challenge by $20 \%$, although there were lesser increases in SOD, RB and antibodies. The administration of PLGA, liposomes and PLGA/liposomes also decreased mortality by 30, 30 and 25\% (Harikrishnan et al., 2012).

\section{Viral antigens encapsulated in PLGA}

Adomako et al. (2010) found that the administration of PLGA particles that encapsulate DNA coding for the G protein of IHNV by intramuscular injection or in feed mixed with soya derivatives caused the expression of the $\mathrm{G}$ protein in $13 \%$ of the vaccinated fish and stimulated antibodies in $15 \%$ of orally vaccinated fish and $27 \%$ of those vaccinated by intramuscular injection vaccination also protected a low percentage of rainbow trout against IHNV at 6 weeks of challenge, but this percentage was higher than that protected by naked DNA administered by IM. The authors note that the release of DNA from nanoparticles is too low at $14^{\circ} \mathrm{C}$ to explain the low levels of transfection. However, they note that at $\mathrm{pH} 4 ; 7.7$ and 8.4 a large amount of DNA was released in the first hour of incubation (15\% at $\mathrm{pH} 4$ and $20-25 \%$ at $\mathrm{pH} 7.7$ and 8.4 ). This indicates that while the vaccine can be incorporated into different organs of the fish, this is not enough for an efficient expression of the DNA and that for DNA vaccines that are administered orally, the PLGA particles should be stabilized so that they do not degrade in the $\mathrm{pH}$ of the stomach and instead are incorporated by the cells in the intestine and can release the DNA in the cell nucleus to allow its expression (Adomako et al., 2012).

The PLGA nanoparticles of two strains of IPNV inactivated in formalin and administered to Atlantic salmon intraperitoneally stimulates antibodies to a comparable level to that provoked by inactivated virus administered in oily adjuvant or the recombinant VP2 protein. Nevertheless, the level of protection against IPNV is lower (Munang andu et al., 2012).

The oral administration through filling-stomach syringes of PLGA of DNA encoding for a LCDV protein allows for the detection of a low quantity of 500-nm nanoparticles in the blood at two hours, with an increase at 8 hours (Tian \& Yu 2011) and allows for the protein to be detected in gills, intestine, spleen and kidneys up to 90 days (Tian et al., 2008; Tian \& Yu 2011). The nanoparticle vaccine stimulated the immune response, causing a significant increase in the number of antibodies and reaching a maximum at six to nine weeks post-vaccination (Tian \& Yu 2011) compared to naked DNA with microparticles of approximately $1 \mu \mathrm{m}$ (Tian et al., 2008). The vaccination can induce a significant response in respiratory and proPO activity, suggesting an increase in phagocytosis and levels of SOD, lysozymes and antibodies also increase. This vaccine provides marked protection to Japanese flounders against the production of tumors. According to the Pearson correlation, only the antibodies in serum 
did not correlate with the rest of the immune parameters obtained, indicating that this increase is not relevant to immunostimulation (Tian \& Yu 2011).

Parasitic antigens encapsulated in PLGA

In the only study on parasites, the i-antigen (i-AG) of Uronema marinum was obtained by disrupting a expressing bacterin of, which was encapsulated in PLGA nanoparticles and administered intraperitoneally to Kelp grouper (Epinephelus bruneus). The administration of the nanoparticles increased the levels of lysozyme, RB, antiprotease, serum b2-macroglobulin and complement at post-vaccination weeks 1, 2 and 4 . Antibodies increased to levels similar to when I-AG is injected naked. This vaccination succeeded in providing protection against infection, reaching an RPS of $20 \%$, while the antigen without encapsulation and the empty PLGA nanoparticles reached RPS of 30 and $40 \%$ respectively (Harikrishnan et al., 2012).

This result is promising in the use of PLGA particles in encapsulating antigens against parasitic diseases such as Caligus rogercresseyi, also known as Lepeophtheirus salmonis, which has caused major losses in the aquaculture industry worldwide.

\section{DISCUSSION}

Research into generating particles to encapsulate molecules to be delivered to aquaculture species is in its initial stages. Published results show a great variation in efficacy depending on the method of administering the vaccine, the fish species and the method of encapsulation, among other factors. Unfortunately, the techniques employed in encapsulation are not often detailed. Likewise, there is often no characterization of the particles in terms of size, shape and physicalchemical properties, which makes it difficult to deduce what characteristics a particle should have to be efficient in the delivery of drugs to fish species. In general, the methods used are extrapolation to fish of the same strategies used with mammals, which could explain the low efficiency of these strategies. The environments in which mammals and fish live are different, as are the immune responses, the target cells, the tissue and organs and the pathogens that infect them.

In general, the administration of particles by IP has permitted the development of protection against the pathogen, while the oral administration of these vaccines offers low levels of protection, although with notable exceptions (De Las Heras et al., 2010; Tian \& Yu 2011; Tian et al., 2008). Good results have also been obtained evaluating the use of antigenencapsulating particles as a method for oral administration of boosters (Altun et al., 2010; Romalde et al., 2004), which offers a good non-invasive alternative for vaccinating fish. These results indicate that it is possible to develop encapsulating particles for oral administration, although improvements in their design are required.

As with evaluations of other fish vaccines, experiments with nanoparticle and microparticle vaccines show that the levels of neutralizing antibodies do not correlate with the degree of protection provided by the vaccine (Cuesta et al., 2010; De Las Heras et al., 2010; Dorson et al., 1978; Koellner \& Kotterba 2002). Even when the number of antibodies increases, the Pearson correlation shows that the increase is not related to the protection against LCDV (Tian \& Yu 2011). Notably, these antibodies are generally detected in serum and do not determine the effect of vaccination on the mucosal antibodies. The mucosal immunity in fish has not been well studied. It would be important to determine if the mucosal response correlates with the level of protection in order to develop methods of delivering vaccines that can activate mucosal antibodies. This would be highly compatible with the development of oral or immersion-based vaccines that allow for the primary action of the antigen with the mucous of the intestine, stomach and gills. Consequently, it is also important to keep in mind that the choice of method of inoculation can depend on the type of pathogen and the target organ that is infected. Oral vaccines accumulate in the intestine, injected vaccines in the abdominal cavity or in the muscles, and vaccines by immersion accumulate in the gills. In this respect, the choice of cells to deliver the vaccine, such as APC or target cells of the pathogen is limited by lack of knowledge about the characteristics of fish cells, which differ in several respects from mammalian cells. Among the differences are slower growth at lower temperatures of fish cells, less sensitivity to toxic compounds, and different compositions of membranes and proteins of different amino acid sequences that carry out the same functions in the cells of fish and that are not immunogenic in that they can generate antibodies to detect them. There are cell types in fish that have not been clearly identified in mammals, such as nucleated erythrocytes (Glomski et al., 1992), phagocyted lymphocytes B (Li et al., 2006) and finally organs that bring together the functions of several organs in mammals or functions in fish that are different from those in mammals. It is necessary to understand these differences in fish cells in order to design vaccination methods for efficient delivery to the organs and cells of the fish.

Added to the above, different fish species have different responses to vaccination (Joosten et al., 1997), so that the methods of encapsulation may not be transferable from one species to another. As well, encapsulated antigens modify the physical-chemical characteristics of the particle so that the results of assays on stability, physical-chemical parameters and the location in organs cannot be extrapolated from one molecule to another using the same encapsulating particle. Similarly, the characteristics of the antigen can be changed when it is encapsulated, because of which the function, structure, stability and immunogenicity of the antigen needs to be maintained and verified.

It has been demonstrated that the use of encapsulating DNA particles that encodes for pathogenic proteins provides a high level of protection in fish against pathogens when alginate, chitosan and PLGA are used. Results have been very promising given that the inoculation of DNA has been shown to be very effective with fish. In fact, antigen-coding naked DNA has been highly effective against a variety of viral strains of rhabdovirus among different fish species in different states of development (Kim et al., 2000; Lapatra et al., 2001; Lorenzen et al., 2002), leading to the development of a commercial prototype against IHNV by Aqua Health Ltd in Canada, which is the only country that has allowed the use of DNA vaccines in fish farming. The advantages of DNA vaccines are their safety, it being impossible that they cause infection. They avoid the synthesis of antigenic protein, trigger long-term immune and humoral response, are effective in early stages of growth, 
and are inexpensive and easily stored. The administration of DNA in fish stimulates the expression of MHC class II and the presence of unmethylated $\mathrm{CpG}$ activates macrophages, causes the proliferation of leukocytes and stimulates the expression of cytokines (Lee et al., 2003; Tassakka \& Sakai 2004; Boudinot et al., 1998; Meng et al., 2003; Tassakka \& Sakai 2003), acting as adjuvants (Kanellos et al., 1999; Martinez-Alonso et al., 2011). The disadvantage of these vaccines is that naked DNA must be administered by intramuscular injection (Salgado-Miranda et al., 2013) or by particle-mediated delivery by gene guns (Corbeil et al., 2000; Gomez-Chiarri et al., 1996; Sudha et al., 2001), given that oral administration causes degradation of the DNA due to the low $\mathrm{pH}$ level in the stomach and the DNases in the gastrointestinal tract. Consequently, adequate DNA encapsulation would be the ideal way to administer these vaccines orally.

The current use of particles to deliver antivirals or antibiotics in viral or bacterial target cells or of immunostimulants that can maintain a state of immunity in fish has been reported. These can be co-administered with vaccines to strengthen them.

Finally, legislation is needed that allows for the use of particles to administer drugs to fish orally or by immersion. The safety of the vaccines needs to be studied, given that the vaccination material can escape to the environment from immersion pools or corrals during vaccination, making it possible that there will be human contact with the vaccine. As well, there need to be studies of the adverse effects on fish. A correct protocol based on knowledge of adverse effects can result in appropriate use of encapsulating particles in fish farming.

All of the above indicates that antigen encapsulation of fish vaccines is very promising, although more research is needed to develop specific encapsulation methods for fish vaccines that stimulate adequate immune responses.

\section{ACKNOWLEDGEMENTS}

The authors are grateful for the financial support from Fondecyt Project 3120149 and Conicyt Project ACE-02. The authors are also grateful to Dr. Monica Imarai for her valuable comments and suggestions.

\section{REFERENCES}

ADOMAKO M, ST-HILAIRE S, ZHENG Y, ELEY J, MARCUM RD, SEALEY W, DONAHOWER BC, LAPATRA S, SHERIDAN PP (2012) Oral DNA vaccination of rainbow trout, Oncorhynchus mykiss (Walbaum), against infectious haematopoietic necrosis virus using PLGA [Poly(D,L-LacticCo-Glycolic Acid)] nanoparticles. J Fish Dis 35(3):203-214.

AGNIHOTRI SA, MALLIKARIUNA NN, AMINABHAVI TM (2004) Recent advances on chitosan-based micro- and nanoparticles in drug delivery. J Control Release 100(1):5-28.

ALTUN S, KUBILAY A, EKICI S, DIDINEN BI, DILER Ö (2010) Oral Vaccination Against Lactococcosis in Rainbow Trout (Oncorhynchus mykiss) Using Sodium Alginate and Poly (lactide-co-glycolide) Carrier. Journal of the Faculty of Veterinary Medicine, University of Kafkas, Kars 16:211-217.

ALTUN S, KUBILAY A, EKICI S, DIDINEN BI, DILER Ö (2010) Oral vaccination against Lactococcosis in Rainbow Trout (Oncorhynchus mykiss) Using Sodium Alginate and Poly (lactide-co-glycolide) carrier. Kafkas Univ Vet Fak Derg 16:211-217.

AUDRAN R, PETER K, DANNULL J, MEN Y, SCANDELLA E, GROETTRUP M, GANDER B, CORRADIN G (2003) Encapsulation of peptides in biodegradable microspheres prolongs their MHC class-I presentation by dendritic cells and macrophages in vitro. Vaccine 21(1112):1250-1255
BANCHEREAU J, STEINMAN RM (1998) Dendritic cell and the control of immunity. Nature 392(6673):245-252.

BANCHEREAU J, ZURAWSKI S, THOMPSON-SNIPES L, BLANCK JP, CLAYTON S, MUNK A, CAO Y, WANG Z, KHANDELWAL S, HU J, MCCOY WHT, PALUCKA KA, REITER Y, FREMONT DH, ZURAWSKI G, COLONNA M, SHAW AS, KLECHEVSKY E (2012) Immunoglobulinlike transcript receptors on human dermal CD14+ dendritic cells act as a CD8-antagonist to control cytotoxic T cell priming. Proc Natl Acad Sci U S A 109(46):18885-18890.

BASSITY E, CLARK TG (2012) Functional identification of dendritic cells in the teleost model, rainbow trout (Oncorhynchus mykiss). PLoS One 7(3):e33196.

BEHERA T, NANDA PK, MOHANTY C, MOHAPATRA D, SWAIN P, DAS BK, ROUTRAY P, MISHRA BK, SAHOO SK (2010) Parenteral immunization of fish, Labeo rohita with Poly D, L-lactide-co-glycolic acid (PLGA) encapsulated antigen microparticles promotes innate and adaptive immune responses. Fish Shellfish Immunol 28(2):320-325.

BERG A, RODSETH OM, TANGERAS A, HANSEN T (2006) Time of vaccination influences development of adhesions, growth and spinal deformities in Atlantic salmon Salmo salar. Diseases of aquatic organisms 69(2-3):239-248.

BORGES O, SILVA M, DE SOUSA A, BORCHARD G, JUNGINGER HE, CORDEIRO-DA-SILVA A (2008) Alginate coated chitosan nanoparticles are an effective subcutaneous adjuvant for hepatitis B surface antigen International immunopharmacology 8(13-14):1773-1780.

BOUDINOT P, BLANCO M, DE KINKELIN P, BENMANSOUR A (1998) Combined DNA immunization with the glycoprotein gene of viral hemorrhagic septicemia virus and infectious hematopoietic necrosis virus induces double-specific protective immunity and nonspecific response in rainbow trout. Virology 249(2):297-306.

BOWERSOCK TL, HOGENESCH H, SUCKOW M, GUIMOND P, MARTIN S, BORIE D, TORREGROSA S, PARK H, PARK K (1999) Oral vaccination of animals with antigens encapsulated in alginate microspheres. Vaccine 17(13-14):1804-1811.

BRODE S, MACARY PA (2004) Cross-presentation: dendritic cells and macrophages bite off more than they can chew! Immunology 112(3):345351.

BROOS S, LUNDBERG K, AKAGI T, KADOWAKI K, AKASHI M, GREIFF L, BORREBAECK CA, LINDSTEDT M (2010) Immunomodulatory nanoparticles as adjuvants and allergen-delivery system to human dendritic cells: Implications for specific immunotherapy. Vaccine 28(31):5075-5085

BURGDORF S, KURTS C (2008) Endocytosis mechanisms and the cell biology of antigen presentation. Curr Opin Immunol 20(1):89-95.

CARRINGTON AC, SECOMBES CJ (2007) CpG oligodeoxynucleotides upregulate antibacterial systems and induce protection against bacterial challenge in rainbow trout (Oncorhynchus mykiss). Fish Shellfish Immunol 23(4):781-792.

CLAWSON C, HUANG CT, FUTALAN D, SEIBLE DM, SAENZ R, LARSSON M, MA W, MINEV B, ZHANG F, OZKAN M, OZKAN C, ESENER S, MESSMER D (2010) Delivery of a peptide via poly(D,Llactic-co-glycolic) acid nanoparticles enhances its dendritic cellstimulatory capacity. Nanomedicine 6(5):651-661.

COESHOTT CM, SMITHSON SL, VERDERBER E, SAMANIEGO A, BLONDER JM, ROSENTHAL GJ, WESTERINK MA (2004) Pluronic F127-based systemic vaccine delivery systems. Vaccine 22(19):2396-2405.

CORBEIL S, KURATH G, LAPATRA SE (2000) Fish DNA vaccine against infectious hematopoietic necrosis virus: efficacy of various routes of immunisation. Fish Shellfish Immunol 10(8):711-723.

CRUZ LJ, TACKEN PJ, FOKKINK R, FIGDOR CG (2011) The influence of PEG chain length and targeting moiety on antibody-mediated delivery of nanoparticle vaccines to human dendritic cells. Biomaterials 32(28):6791-6803

CUESTA A, CHAVES-POZO E, DE LAS HERAS AI, SAINT-JEAN SR, PEREZ-PRIETO S, TAFALLA C (2010) An active DNA vaccine against infectious pancreatic necrosis virus (IPNV) with a different mode of action than fish rhabdovirus DNA vaccines. Vaccine 28(19):3291-3300.

CHENG AC, CHEN YY, CHEN JC (2008) Dietary administration of sodium alginate and kappa-carrageenan enhances the innate immune response of brown-marbled grouper Epinephelus fuscoguttatus and its resistance against Vibrio alginolyticus. Vet Immunol Immunopathol 121(3-4):206-215.

CHONG CS, CAO M, WONG WW, FISCHER KP, ADDISON WR, KWON GS, TYRRELL DL, SAMUEL J (2005) Enhancement of T helper type 1 immune responses against hepatitis B virus core antigen by PLGA nanoparticle vaccine delivery. J Control Release 102(1):85-99. 
DANHIER F, ANSORENA E, SILVA JM, COCO R, LE BRETON A, PREAT V (2012) PLGA-based nanoparticles: an overview of biomedical applications. J Control Release 161(2):505-522.

DAVIS SS (2006) The use of soluble polymers and polymer microparticles to provide improved vaccine responses after parenteral and mucosal delivery. Vaccine 24 Suppl 2:S2-7-10.

DE LAS HERAS AI, RODRÍGUEZ SAINT-JEAN S, PÉREZ-PRIETO SI (2010) Immunogenic and protective effects of an oral DNA vaccine against infectious pancreatic necrosis virus in fish. Fish Shellfish Immunol 28(4):562-570.

DESAI MP, LABHASETWAR V, AMIDON GL, LEVY RJ (1996) Gastrointestinal uptake of biodegradable microparticles: effect of particle size. Pharm Res 13(12):1838-1845.

DESAI MP, LABHASETWAR V, WALTER E, LEVY RJ, AMIDON GL (1997) The mechanism of uptake of biodegradable microparticles in Caco-2 cells is size dependent. Pharm Res 14(11):1568-157.3

DIWAN M, ELAMANCHILI P, CAO M, SAMUEL J (2004) Dose sparing of CpG oligodeoxynucleotide vaccine adjuvants by nanoparticle delivery. Curr Drug Deliv 1(4):405-412

DIWAN M, ELAMANCHILI P, LANE H, GAINER A, SAMUEL J (2003) Biodegradable nanoparticle mediated antigen delivery to human cord blood derived dendritic cells for induction of primary T cell responses. J Drug Target 11(8-10):495-507.

DOGGETT TA, HARRIS JE (1991) Morphology of the gut associated lymphoid tissue of Oreochromis mossambicus and its role in antigen absorption. Fish \& Shellfish Immunology 1:213-227.

DORSON M, CASTRIC J, TORCHY C (1978) Infectious pancreatic necrosis virus of salmonids: biological and antigenic features of a pathogenic strain and of a non-pathogenic variant selected in RTG-2 cells. J Fish Dis 1(4):309-320.

DOSHI N, PRABHAKARPANDIAN B, REA-RAMSEY A, PANT K, SUNDARAM S, MITRAGOTRI S (2010) Flow and adhesion of drug carriers in blood vessels depend on their shape: a study using model synthetic microvascular networks. J Control Release 146(2):196-200.

ELAMANCHILI P, DIWAN M, CAO M, SAMUEL J (2004) Characterization of poly(D,L-lactic-co-glycolic acid) based nanoparticulate system for enhanced delivery of antigens to dendritic cells. Vaccine 22(19):24062412

ELAMANCHILI P, LUTSIAK CM, HAMDY S, DIWAN M, SAMUEL J (2007) "Pathogen-mimicking" nanoparticles for vaccine delivery to dendritic cells. J Immunother 30(4):378-395.

ELDAR A, HOROVITCZ A, BERCOVIER H (1997) Development and efficacy of a vaccine against Streptococcus iniae infection in farmed rainbow trout. Vet. Immunol. Immunopathol. 56:175- 183.

ESPENES A, PRESS CM, ROOIJEN NV, LANDSVERK T (1997) Apoptosis in phagocytotic cells of lymphoid tissues in rainbow trout (Oncorhynchus mykiss) following administration of clodronate liposomes. Cell Tissue Res 289(2):323-331.

EVENSEN O, BRUDESETH B, MUTOLOKI S (2005) The vaccine formulation and its role in inflammatory processes in fish--effects and adverse effects. Developments in biologicals 121:117-125.

FEHR T, SKRASTINA D, PUMPENS P, ZINKERNAGEL RM (1998) T cellindependent type I antibody response against B cell epitopes expressed repetitively on recombinant virus particles. Proc Natl Acad Sci U S A 95(16):9477-9481.

FERNÁNDEZ-ALONSO M, ÁLVAREZ F, ESTEPA A, BLASCO R, COLL JM (1999) A model to study fish DNA immersion vaccination by using the green fluorescent protein. Journal of Fish Diseases 22(3):237-241.

FERNÁNDEZ-ALONSO M, ROCHA A, COLL JM (2001) DNA vaccination by immersion and ultrasound to trout viral haemorrhagic septicaemia virus. Vaccine 19(23-24):3067-3075.

FISCHER S, SCHLOSSER E, MUELLER M, CSABA N, MERKLE HP, GROETTRUP M, GANDER B (2009) Concomitant delivery of a CTLrestricted peptide antigen and CPG ODN by PLGA microparticles induces cellular immune response. J Drug Target 17(8):652-661

FOGED C, BRODIN B, FROKJAER S, SUNDBLAD A (2005) Particle size and surface charge affect particle uptake by human dendritic cells in an in vitro model. Int J Pharm 298(2):315-322.

FREDRIKSEN BN, GRIP J (2012) PLGA/PLA micro- and nanoparticle formulations serve as antigen depots and induce elevated humoral responses after immunization of Atlantic salmon (Salmo salar L.) Vaccine 30(3):656-667.

FREDRIKSEN BN, SAEVAREID K, MCAULEY L, LANE ME, BOGWALD J, DALMO RA (2011) Early immune responses in Atlantic salmon (Salmo salar L.) after immunization with PLGA nanoparticles loaded with a model antigen and beta-glucan. Vaccine 29(46):8338-8349.
FUJIKI K, MATSUYAMAS H, YANO T (1994) Protective effect of sodium alginates against bacterial infection in common Carp, Cyprinus carpio L. J Fish Dis 17:349-355.

GARINOT M, FIEVEZ V, POURCELLE V, STOFFELBACH F, DES RIEUX A, PLAPIED L, THEATE I, FREICHELS H, JEROME C, MARCHANDBRYNAERT J, SCHNEIDER YJ, PREAT V (2007) PEGylated PLGA-based nanoparticles targeting $\mathrm{M}$ cells for oral vaccination. J Control Release 120(3):195-204.

GEORGOPOULOU U, VERNIER JM (1986) Local immunological response in the posterior intestinal segment of the rainbow trout after oral administration of macromolecules. Developmental and comparative immunology 10(4):529-537.

GHENDON Y, MARKUSHIN S, KRIVTSOV G, AKOPOVA I (2008) Chitosan as an adjuvant for parenterally administered inactivated influenza vaccines. Archives of virology 153(5):831-837.

GLOMSKI CA, TAMBURLIN J, CHAINANI M (1992) The phylogenetic odyssey of the erythrocyte. III. Fish, the lower vertebrate experience. Histology and histopathology 7(3):501-528.

GOFORTH R, SALEM AK, ZHU X, MILES S, ZHANG XQ, LEE JH SANDLER AD (2009) Immune stimulatory antigen loaded particles combined with depletion of regulatory T-cells induce potent tumor specific immunity in a mouse model of melanoma. Cancer Immunol Immunother 58(4):517-530.

GÓMEZ-CASADO E, ESTEPA A, COLL JM (2011) A comparative review on European-farmed finfish RNA viruses and their vaccines. Vaccine 29(15):2657-2671.

GÓMEZ-CHIARRI M, LIVINGSTON SK, MURO-CACHO C, SANDERS S, LEVINE RP (1996) Introduction of foreign genes into the tissue of live fish by direct injection and particle bombardment. Dis. aquat. Organisms 27(1):5-12.

GREGODIARIS G (1990 ) Immunotogicai adyuvants: a role for liposomes. Immunol Today 11:89-97.

GREGORIADIS G, BACON A, CAPARROS-WANDERLEY W, MCCORMACK B (2002) A role for liposomes in genetic vaccination. Vaccine 20 Suppl 5:B1-.

GUPTA RK, ALROY J, ALONSO MJ, LANGER R, SIBER GR (1997) Chronic local tissue reactions, long-term immunogenicity and immunologic priming of mice and guinea pigs to tetanus toxoid encapsulated in biodegradable polymer microspheres composed of poly lactide-coglycolide polymers. Vaccine 15(16):1716-1723.

GUTIERRO I, HERNÁNDEZ RM, IGARTUA M, GASCON AR, PEDRAZ JL (2002) Size dependent immune response after subcutaneous, oral and intranasal administration of BSA loaded nanospheres. Vaccine 21(12):67-77.

HAMDY S, HADDADI A, HUNG RW, LAVASANIFAR A (2011) Targeting dendritic cells with nano-particulate PLGA cancer vaccine formulations. Adv Drug Deliv Rev 63(10-11):943-955.

HAMDY S, HADDADI A, SOMAYAJI V, RUAN D, SAMUEL J (2007) Pharmaceutical analysis of synthetic lipid A-based vaccine adjuvants in poly (D,L-lactic-co-glycolic acid) nanoparticle formulations. J Pharm Biomed Anal 44(4):914-923.

HARDING CV, SONG R (1994) Phagocytic processing of exogenous particulate antigens by macrophages for presentation by class I MHC molecules. J Immunol 153(11):4925-4933.

HARIKRISHNAN R, BALASUNDARAM C, HEO MS (2012) Poly D,Llactide-co-glycolic acid-liposome encapsulated ODN on innate immunity in Epinephelus bruneus against Vibrio alginolyticus. Vet Immunol Immunopathol 147(1-2):77-85.

HARIKRISHNAN R, BALASUNDARAM C, HEO MS (2012) Poly D,L-lactide-co-glycolic acid (PLGA)-encapsulated vaccine on immune system in Epinephelus bruneus against Uronema marinum. Experimental parasitology 131(3):325-332.

HASTEIN T, GUDDING R, EVENSEN O (2005) Bacterial vaccines for fish--an update of the current situation worldwide. Developments in biologicals 121:55-74

HAUGLAND GT, JORDAL AE, WERGELAND HI (2012) Characterization of small, mononuclear blood cells from salmon having high phagocytic capacity and ability to differentiate into dendritic like cells. PLoS One 7(11):e49260.

HE C, HU Y, YIN L, TANG C, YIN C (2010) Effects of particle size and surface charge on cellular uptake and biodistribution of polymeric nanoparticles. Biomaterials 31(13):3657-3666.

HE X, JIANG L, WANG F, XIAO Z, LI J, LIU LS, LI D, REN D, JIN X, LI K, HE Y, SHI K, GUO Y, ZHANG Y, SUN S (2005) Augmented humoral and cellular immune responses to hepatitis B DNA vaccine adsorbed onto cationic microparticles. J Control Release 107(2):357-372. 
HUTTENHUIS HB, RIBEIRO AS, BOWDEN TJ, VAN BAVEL C, TAVERNETHIELE AJ, ROMBOUT JH (2006) The effect of oral immunostimulation in juvenile carp (Cyprinus carpio L.). Fish Shellfish Immunol 21(3):261-271.

JOFFRÉ OP, SEGURA E, SAVINA A, AMIGORENA S (2012) Crosspresentation by dendritic cells. Nat Rev Immunol 12(8):557-569.

JOHANSEN P, CORRADIN G, MERKLE HP, GANDER B (1998) Release of tetanus toxoid from adjuvants and PLGA microspheres: how experimental set-up and surface adsorption fool the pattern. J Control Release 56(1-3):209-217.

JOOSTEN PHM, TIEMERSMA E, THREELS A, CAUMARTIN-DHIEUX C, ROMBOUT JHWM (1997) Oral vaccination of fish against Vibrio anguillarum using alginate microparticles. Fish \& Shellfish Immunology 7:471-485.

KANELLOS TS, SYLVESTER ID, BUTLER VL, AMBALI AG, PARTIDOS CD, HAMBLIN AS, RUSSELL PH (1999) Mammalian granulocytemacrophage colony-stimulating factor and some CpG motifs have an effect on the immunogenicity of DNA and subunit vaccines in fish. Immunology 96(4):507-510.

KATARE YK, MUTHUKUMARAN T, PANDA AK (2005) Influence of particle size, antigen load, dose and additional adjuvant on the immune response from antigen loaded PLA microparticles. Int J Pharm 301(12):149-160.

KATARE YK, PANDA AK (2006) Immunogenicity and lower dose requirement of polymer entrapped tetanus toxoid co-administered with alum. Vaccine 24(17):3599-3608.

KIM CH, JOHNSON MC, DRENNAN JD, SIMON BE, THOMANN E, LEONG JA (2000) DNA vaccines encoding viral glycoproteins induce nonspecific immunity and Mx protein synthesis in fish. J Virol 74(15):7048-7054

KOELLNER B, KOTTERBA G (2002) Temperature dependent activation of leucocyte populations of rainbow trout, Oncorhynchus mykiss, after intraperitoneal immunisation with Aeromonas salmonicida. Fish \& Shellfish Immunology 12:35-48.

KOPPANG EO, BJERKAS I, HAUGARVOLL E, CHAN EK, SZABO NJ, ONO N, AKIKUSA B, JIRILLO E, POPPE TT, SVEIER H, TORUD B, SATOH M (2008) Vaccination-induced systemic autoimmunity in farmed Atlantic salmon. J Immunol 181(7):4807-4814.

KOPPANG EO, HAUGARVOLL E, HORDVIK I, AUNE L, POPPE TT (2005) Vaccine-associated granulomatous inflammation and melanin accumulation in Atlantic salmon, Salmo salar L., white muscle. J Fish Dis 28(1):13-22.

KOPPOLU B, ZAHAROFF DA (2013) The effect of antigen encapsulation in chitosan particles on uptake, activation and presentation by antigen presenting cells. Biomaterials 34(9):2359-2369.

KOVEN W, BARR Y, HADAS E, BEN-ATIA I, CHEN Y, WEISS R, TANDLER A (1999) The potential of liposomes as a nutrient supplement in frstfeeding marine ${ }^{\circledR}$ sh larvae. Aquaculture Nutrition 5:251-256.

LAPATRA SE, CORBEIL S, JONES GR, SHEWMAKER WD, LORENZEN N, ANDERSON ED, KURATH G (2001) Protection of rainbow trout against infectious hematopoietic necrosis virus four days after specific or semispecific DNA vaccination. Vaccine 19(28-29):4011-4019.

LAVELLE EC, JENKINS PG, HARRIS JE (1997) Oral immunization of rainbow trout with antigen microencapsulated in poly(DL-lactide-coglycolide) microparticles. Vaccine. 15(10):1070-1078.

LEAL C, CARVALHO-CASTRO G, SACCHETIN P, LOPES C, MORAES A, FIGUEIREDO HCP (2010) Oral and parenteral vaccines against Flavobacterium columnare: evaluation of humoral immune response by ELISA and in vivo efficiency in Nile tilapia (Oreochromis niloticus). Aquaculture International, 18(4):657-666(610).

LEE CH, JEONG HD, CHUNG JK, LEE HH, KIM KH (2003) CpG motif in synthetic ODN primes respiratory burst of olive flounder Paralichthys olivaceus phagocytes and enhances protection against Edwardsiella tarda. Diseases of aquatic organisms 56(1):43-48.

LEMOINE D, WAUTERS F, BOUCHEND'HOMME S, PRÉAT V (1998) Preparation and characterization of alginate microspheres containing a model antigen. International Journal of Pharmaceutics 176(1): 9-19.

LI J, BARREDA DR, ZHANG YA, BOSHRA H, GELMAN AE, LAPATRA S, TORT L, SUNYER JO (2006) B lymphocytes from early vertebrates have potent phagocytic and microbicidal abilities. Nature immunology 7(10):1116-1124.

LI X, XU Y, CHEN G, WEI P, PING Q (2008) PLGA nanoparticles for the oral delivery of 5-Fluorouracil using high pressure homogenizationemulsification as the preparation method and in vitro/in vivo studies. Drug Dev Ind Pharm 34(1):107-115.
LILLEHAUG A (1989) Oral immunization of rainbow trout, Salmo gairdneri Richardson, against vibriosis with vaccines protected against digestive degradation. Journal of Fish Diseases 12:579-584.

LIM F, SUN AM (1980) Microencapsulated islets as bioartificial endocrine pancreas. Science 210(4472):908-910.

LORENZEN N, LORENZEN E, EINER-JENSEN K, LAPATRA SE (2002) Immunity induced shortly after DNA vaccination of rainbow trout against rhabdoviruses protects against heterologous virus but not against bacterial pathogens. Developmental and comparative immunology 26(2):173-179.

LU JM, WANG X, MARIN-MULLER C, WANG H, LIN PH, YAO Q, CHEN C (2009) Current advances in research and clinical applications of PLGAbased nanotechnology. Expert Rev Mol Diagn 9(4):325-341.

LUGO-VILLARINO G, BALLA KM, STACHURA DL, BANUELOS K, WERNECK MB, TRAVER D (2010) Identification of dendritic antigenpresenting cells in the zebrafish. Proc Natl Acad Sci U S A 107(36):1585015855.

LUMSDEN JS, FERGUSON HW (1994) Isolation and partial characterization of rainbow trout (Oncorhynchus mykiss) gill mucin. Fish Physiol Biochem. 12(5):387-398.

LUTSIAK ME, ROBINSON DR, COESTER C, KWON GS, SAMUEL J (2002) Analysis of poly(D,L-lactic-co-glycolic acid) nanosphere uptake by human dendritic cells and macrophages in vitro. Pharm Res 19(10):1480-1487

MA Y, ZHAO X, LI J, SHEN Q (2012) The comparison of different daidzeinPLGA nanoparticles in increasing its oral bioavailability. Int J Nanomedicine 7:559-570.

MAKADIA HK, SIEGEL SJ (2011) Poly Lactic-co-Glycolic Acid (PLGA) as Biodegradable Controlled Drug Delivery Carrier. Polymers (Basel) 3(3):1377-1397

MANOLOVA V, FLACE A, BAUER M, SCHWARZ K, SAUDAN P, BACHMANN MF (2008) Nanoparticles target distinct dendritic cell populations according to their size. Eur J Immunol 38(5):1404-1413.

MARTÍNEZ-ALONSO S, MARTINEZ-LOPEZ A, ESTEPA A, CUESTA A TAFALLA C (2011) The introduction of multi-copy CpG motifs into an antiviral DNA vaccine strongly up-regulates its immunogenicity in fish Vaccine 29(6):1289-1296.

MAURICE S, NUSSINOVITCH A, JAFFE N, SHOSEYOV O, GERTLER A (2004) Oral immunization of Carassius auratus with modified recombinant A-layer proteins entrapped in alginate beads. Vaccine 23(4):450-459.

MBOW ML, DE GREGORIO E, VALIANTE NM, RAPPUOLI R (2010) New adjuvants for human vaccines. Curr Opin Immunol 22(3):411-416.

MENG Z, SHAO J, XIANG L (2003) CpG oligodeoxynucleotides activate grass carp (Ctenopharyngodon idellus) macrophages. Developmental and comparative immunology 27(4):313-321.

MESHKINI S, TAFY A-A, TUKMECHI A, FARHANG-PAJUH F (2012) Effects of chitosan on hematological parameters and stress resistance in rainbow trout (Oncorhynchus mykiss). Veterinary Research Forum. 3(1):49-54.

MIDTLYNG PJ (1997) Vaccinated fish welfare: protection versus side-effects. Dev Biol Stand 90:371-379.

MORACHIS JM, MAHMOUD EA, ALMUTAIRI A (2012) Physical and chemical strategies for therapeutic delivery by using polymeric nanoparticles. Pharmacol Rev 64(3):505-519.

MUNANG'ANDU HM, FREDRIKSEN BN, MUTOLOKI S, BRUDESETH B, KUO TY, MARJARA IS, DALMO RA, EVENSEN O (2012) Comparison of vaccine efficacy for different antigen delivery systems for infectious pancreatic necrosis virus vaccines in Atlantic salmon (Salmo salar L.) in a cohabitation challenge model. Vaccine 30(27):4007-4016.

NAGAMOTO T, HATTORI Y, TAKAYAMA K, MAITANI Y (2004) Novel chitosan particles and chitosan-coated emulsions inducing immune response via intranasal vaccine delivery. Pharm Res 21(4):671-674.

NAHA PC, KANCHAN V, MANNA PK, PANDA AK (2008) Improved bioavailability of orally delivered insulin using Eudragit-L30D coated PLGA microparticles. J Microencapsul 25(4):248-256.

NAKATANI M, IWASAKI T, WATARAI S, KODAMA H (2007) In vitro enhancement by CPG ODN of phagocytic activity of rainbow trout head kidney phagocytes against fish pathogen Vibrio ordalii, but not against polystyrene particles. J Vet Med Sci 69(12):1287-1290

NAKHLA AN, SZALAI AJ, BANOUB JH, KEOUGH KMW (1994) Uptake and biodistribution of free and liposomally incorporated lipopolysaccharide of Aeromonas salmonicida administered via different routes to rainbow trout (Oncorhynchus mykiss). . Journal of Liposome Research. 4:1029-11048. 
NAKHLA AN, SZALAI AJ, BANOUB JH, KEOUGH KMW (1997) Serum antiLPS antibody production by rainbow trout (Oncorhynchus mykiss) in response to the administration of free and liposomally-incorporated LPS from Aeromonas salmonicida. Fish \& Shellfish Immunology 7:387-401.

NISHIMURA K, NISHIMURA S, NISHI N, SAIKI I, TOKURA S, AZUMA I (1984) Immunological activity of chitin and its derivatives. Vaccine 2(1):93-99.

NORTON LW, PARK J, BABENSEE JE (2010) Biomaterial adjuvant effect is attenuated by anti-inflammatory drug delivery or material selection. J Control Release 146(3):341-348.

O'DONNELL GB, REILLY P, DAVIDSON GA, ELLIS AE (1996) The uptake of human gamma globulin incorporated into poly (D,L-lactide-coglycolide) microparticles following oral intubation in Atlantic salmon, Salmo salar L. Fish \& Shellfish Immunology. 6:507-520.

OUJI Y, YOSHIDA-TERAKURA A, HAYASHI Y, MAEDA I, KAWASE M, YAMATO E, MIYAZAKI J, YAGI K (2002) Polyethyleneimine/chitosan hexamer-mediated gene transfection into intestinal epithelial cell cultured in serum-containing medium. J Biosci Bioeng 94(1):81-83.

OWENS DE, 3RD, PEPPAS NA (2006) Opsonization, biodistribution, and pharmacokinetics of polymeric nanoparticles. Int J Pharm 307(1):93-102.

PANDEY R, KHULLER GK (2007) Nanoparticle-based oral drug delivery system for an injectable antibiotic - streptomycin. Evaluation in a murine tuberculosis model. Chemotherapy 53(6):437-441.

PANYAM J, ZHOU WZ, PRABHA S, SAHOO SK, LABHASETWAR V (2002) Rapid endo-lysosomal escape of poly(DL-lactide-co-glycolide) nanoparticles: implications for drug and gene delivery. FASEB J 16(10):1217-1226.

PARRA D, RIEGER AM, LI J, ZHANG YA, RANDALL LM, HUNTER CA, BARREDA DR, SUNYER JO (2012) Pivotal advance: peritoneal cavity B-1 B cells have phagocytic and microbicidal capacities and present phagocytosed antigen to CD4+ T cells. Journal of leukocyte biology 91(4):525-536.

PELUSO G, PETILLO O, RANIERI M, SANTIN M, AMBROSIO L, CALABRO D, AVALLONE B, BALSAMO G (1994) Chitosan-mediated stimulation of macrophage function. Biomaterials 15(15):1215-1220.

PETTERSEN EF, INGERSLEV HC, STAVANG V, EGENBERG M, WERGELAND HI (2008) A highly phagocytic cell line TO from Atlantic salmon is CD83 positive and M-CSFR negative, indicating a dendriticlike cell type. Fish Shellfish Immunol 25(6):809-819.

POLK AE, AMSDEN B, SCARRATT DJ, GONZAL A, OKHAMAFE AO, GOOSEN MFA (1994) Oral delivery in aquaculture: Controlled release of proteins from chitosan-alginate microcapsules. Aquacultural Engineering. 13(4):311-323.

POOLEY JL, HEATH WR, SHORTMAN K (2001) Cutting edge: intravenous soluble antigen is presented to CD4 T cells by CD8- dendritic cells, but cross-presented to CD8 T cells by CD8+ dendritic cells. J Immunol 166(9):5327-5330.

POPPE TT, BRECK. O (1997) Pathology of Atlantic salmon Salmo salar intraperitoneally immunized with oil-adjuvanted vaccine: a case report. Dis Aquat Org. 29:219-226.

PORPORATTO C, BIANCO ID, CORREA SG (2005) Local and systemic activity of the polysaccharide chitosan at lymphoid tissues after oral administration. Journal of leukocyte biology 78(1):62-69.

POWER CA, MARKHAM RJF, DONALD AW (1990) Uptake and tissue distribution of liposomes after intraperitoneal administration to rainbow trout, Oncorhynchus mykiss (Richardson): a preliminary report. Journal of Fish Diseases. 13:329-332.

PRIDGEON JW, KLESIUS PH, MU X, YANCEY RJ, KIEVIT MS, DOMINOWSKI PJ (2012) Efficacy of QCDCR formulated CpG ODN 2007 in Nile tilapia against Streptococcus iniae and identification of upregulated genes. Vet Immunol Immunopathol 145(1-2):179-190.

PROKOP A, DAVIDSON JM (2008) Nanovehicular intracellular delivery systems. J Pharm Sci 97(9):3518-3590.

QUENTEL C, VIGNEULLE M (1997) Antigen uptake and immune responses after oral vaccination. Dev Biol Stand 90:69-78.

RAJESH KUMAR S, ISHAQ AHMED VP, PARAMESWARAN V, SUDHAKARAN R, SARATH BABU V, SAHUL HAMEED AS (2008) Potential use of chitosan nanoparticles for oral delivery of DNA vaccine in Asian sea bass (Lates calcarifer) to protect from Vibrio (Listonella) anguillarum. Fish Shellfish Immunol 25(1-2):47-56.

RAMOS EA, RELUCIO JL, TORRES-VILLANUEVA CA (2005) Gene expression in tilapia following oral delivery of chitosan-encapsulated plasmid DNA incorporated into fish feeds. Marine biotechnology $7(2): 89-94$.
REDDY ST, REHOR A, SCHMOEKEL HG, HUBBELL JA, SWARTZ MA (2006) In vivo targeting of dendritic cells in lymph nodes with poly(propylene sulfide) nanoparticles. J Control Release 112(1):26-34.

RODGERS CJ (1990) Immersion vaccination for control of fish furunculosis. Dis Aquat Org. 8:69-72.

RODRIGUES AP, HIRSCH D, FIGUEIREDO HCP, LOGATO PVR, MORAES AM (2006) Production and characterisation of alginate microparticles incorporating Aeromonas hydrophila designed for fish oral vaccination. Process Biochem 41:638-643.

RODRÍGUEZ-PINTO D (2005) B cells as antigen presenting cells. Cell Immunol 238(2):67-75

ROMALDE JL, LUZARDO-ÁLVAREZ A, RAVELO C, TORANZO AE, BLANCO-MENDEZ J (2004) Oral immunization using alginate microparticles as a useful strategy for booster vaccination against fish lactococcosis. Aquaculture 236:119-129.

ROMALDE JL, MARGARIÑOS B, TORANZO AE (1999) Prevention of streptococcosis in turbot by intraperitoneal vaccination:a review. J. Appl. Ichthyol 15:153-158.

ROMBOUT JHWM, BERG AA, BERG CTGA, WITTE P, EGBERTS E (2006) mmunological importance of the second gut segment in carp. III. Systemic and/or mucosal immune responses after immunization with soluble or particulate antigen. Journal of Fish Biology 35(2):79 - 186.

ROMBOUT JHWM, VAN DEN BERG AA, VAN DER BERG CTGA, WITTE P, EGBERTS E (1989) Immunological importance of the second gut segment of carp. III. Systemic and/or mucosal immune responses after immunization with soluble or particulate antigen. . Journal of Fish Biology 35:179-186.

ROMOREN K, THU BJ, SMISTAD G, EVENSEN O (2002) Immersion delivery of plasmid DNA. I. A study of the potentials of a liposomal delivery system in rainbow trout (Oncorhynchus mykiss) fry. J Control Release 85(1-3):203-213.

SALGADO-MIRANDA C, LOZA-RUBIO E, ROJAS-ANAYA E, GARCÍAESPINOSA G (2013) Viral vaccines for bony fish: past, present and future. Expert review of vaccines 12(5):567-578.

SALINAS I, ZHANG YA, SUNYER JO (2011) Mucosal immunoglobulins and B cells of teleost fish. Developmental and comparative immunology 35(12):1346-1365.

SCHLOSSER E, MUELLER M, FISCHER S, BASTA S, BUSCH DH, GANDER B, GROETTRUP M (2008) TLR ligands and antigen need to be coencapsulated into the same biodegradable microsphere for the generation of potent cytotoxic $\mathrm{T}$ lymphocyte responses. Vaccine 26(13):1626-1637.

SHAIKH J, ANKOLA DD, BENIWAL V, SINGH D, KUMAR MN (2009) Nanoparticle encapsulation improves oral bioavailability of curcumin by at least 9-fold when compared to curcumin administered with piperine as absorption enhancer. Eur J Pharm Sci 37(3-4):223-230.

SHEN H, ACKERMAN AL, CODY V, GIODINI A, HINSON ER, CRESSWELL P, EDELSON RL, SALTZMAN WM, HANLON DJ (2006) Enhanced and prolonged cross-presentation following endosomal escape of exogenous antigens encapsulated in biodegradable nanoparticles. Immunology 117(1):78-88.

SIGAL LJ, CROTTY S, ANDINO R, ROCK KL (1999) Cytotoxic T-cell immunity to virus-infected non-haematopoietic cells requires presentation of exogenous antigen. Nature 398(6722):77-80.

SINGH M, SRIVASTAVA I (2003) Advances in vaccine adjuvants for infectious diseases. Current HIV research 1(3):309-320.

SKJERMO J, BERGHB $\varnothing$ (2004) High-M alginate immunostimulation of Atlantic halibut (Hippoglossus hippoglossus L.) larvae using Artemia for delivery, increases resistance against vibriosis. Aquaculture 238(14):107-113.

SKJERMO J, DEFOORT T, DEHASQUE M, ESPEVIK T, OLSEN Y, SKJAK BRAEK G, SORGELOOS P, VADSTEIN O (1995) Immunostimulation of juvenile turbot Scophthalmus maximus L. using an alginate with high mannuronic acid content administered via the live food organism Artemia. Fish and Shellfish Immunology 5(7): 531-534. Fish and Shellfish Immunology 5(7):531-534.

SOMMERSET I, KROSSOY B, BIERING E, FROST P (2005) Vaccines for fish in aquaculture. Expert review of vaccines 4(1):89-101.

SUDHA P, S. L, KWANG J, GONG Z (2001) Multiple tissue transformation in adult zebrafish by gene gun bombardment and muscular injection of naked DNA Mar Biotechnol (NY). 3(2):19-25.

SZELEI J, VARADI L, MULLER F, ERDIELYI F, ORBAN L, HORVATH L, DUDA E (1994) Liposome-mediated gene transfer in fish embryos. Transgenic Research. 3:116-119.

TAFAGHODI M, TABASI S, PAYANA M (2007) Alginate Microsphere as a Delivery System and Adjuvant for Autoclaved Leishmania major and 
Quillaja Saponin: Preparation and Characterization. Iranian Journal of Pharmaceutical Sciences 3(2):61-68.

TAMBER H, JOHANSEN P, MERKLE HP, GANDER B (2005) Formulation aspects of biodegradable polymeric microspheres for antigen delivery. Adv Drug Deliv Rev 57(3):357-376.

TANAKA H, MATSUMURA M, VELIKY IA (1984) Diffusion characteristics of substrates in Ca-alginate gel beads. Biotech. Bioeng. 26:53-58.

TASSAKKA A, SAKAI M (2003) The in vitro effect of CpG-ODNs on the innate immune response of common carp, Cyprinus carpio L. . Aquaculture 220:27-36.

TASSAKKA A, SAKAI M (2004) Expression of immune-related genes in the common carp (Cyprinus carpio L.) after stimulation by $\mathrm{CpG}$ oligodeoxynucleotides. . Aquaculture 242:1-12.

THIELE L, ROTHEN-RUTISHAUSER B, JILEK S, WUNDERLIALLENSPACH H, MERKLE HP, WALTER E (2001) Evaluation of particle uptake in human blood monocyte-derived cells in vitro. Does phagocytosis activity of dendritic cells measure up with macrophages? J Control Release 76(1-2):59-71.

TIAN J, SUN X, CHEN X, YU J, QU L, WANG L (2008) The formulation and immunisation of oral poly(DL-lactide-co-glycolide) microcapsules containing a plasmid vaccine against lymphocystis disease virus in Japanese flounder (Paralichthys olivaceus). International immunopharmacology 8(6):900-908.

TIAN J, YU J (2011) Poly(lactic-co-glycolic acid) nanoparticles as candidate DNA vaccine carrier for oral immunization of Japanese flounder (Paralichthys olivaceus) against lymphocystis disease virus. Fish Shellfish Immunol 30(1):109-117.

TIAN J, YU J, SUN X (2008) Chitosan microspheres as candidate plasmid vaccine carrier for oral immunisation of Japanese flounder (Paralichthys olivaceus). Vet Immunol Immunopathol 126(3-4):220-229.

TIAN JY, SUN XQ, CHEN XG (2008) Formation and oral administration of alginate microspheres loaded with pDNA coding for lymphocystis disease virus (LCDV) to Japanese flounder. Fish Shellfish Immunol 24(5):592-599.

TOYOKAWA H, NAKAO A, BAILEY RJ, NALESNIK MA, KAIZU T, LEMOINE JL, IKEDA A, TOMIYAMA K, PAPWORTH GD, HUANG L, DEMETRIS AJ, STARZL TE, MURASE N (2008) Relative contribution of direct and indirect allorecognition in developing tolerance after liver transplantation. Liver transplantation : official publication of the American Association for the Study of Liver Diseases and the International Liver Transplantation Society 14(3):346-357.
TYAGI RK, GARG NK, SAHU T (2012) Vaccination Strategies against Malaria: novel carrier(s) more than a tour de force. J Control Release 162(1):242-254.

VALLEJO AN, MILLER NW, HARVEY NE, CUCHENS MA, WARR GW CLEM LW (1992) Cellular pathway(s) of antigen processing and presentation in fish APC: endosomal involvement and cell-free antigen presentation. Dev Immunol 3(1):51-65.

VERT M, MAUDUIT J, LI S (1994) Biodegradation of PLA/GA polymers: increasing complexity. Biomaterials 15(15):1209-1213.

WALDEN P, NAGY ZA, KLEIN J (1986) Major histocompatibility complexrestricted and unrestricted activation of helper $\mathrm{T}$ cell lines by liposomebound antigens. The Journal of molecular and cellular immunology : JMCI 2(4):191-197.

WALSH MC, BANAS JA, MUDZINSKI SP, PREISSLER MT, GRAZIANO RF, GOSSELIN EJ (2003) A two-component modular approach for enhancing T-cell activation utilizing a unique anti-FcgammaRIstreptavidin construct and microspheres coated with biotinylatedantigen. Biomolecular engineering 20(1):21-33.

WANG G, PAN L, ZHANG Y (2011) Approaches to improved targeting of DNA vaccines. Human vaccines 7(12):1271-1281.

WANG XM, RUAN Y, XIE QD, HUANG TH (2005) [Research on gene transfer by spermatozoa]. Yi chuan $=$ Hereditas / Zhongguo yi chuan xue hui bian ji 27(2):195-200.

WEE S, GOMBOTZ WR (1998) Protein release from alginate matrices. Adv Drug Deliv Rev 31(3):267-285.

WETZEL SA, PARKER DC (2006) MHC transfer from APC to T cells following antigen recognition. Crit Rev Immunol 26(1):1-21.

WONG G, KAATTARI, S. L. \& CHRISTENSEN, J. M. (1992) E\#ectiveness of an oral enteric coated Vibrio vaccine for use in salmonid fish. Immunological Investigations 21:353-364.

YEH SP, CHANG CA, CHANG CY, LIU CH, CHENG W (2008) Dietary sodium alginate administration affects fingerling growth and resistance to Streptococcus sp. and iridovirus, and juvenile non-specific immune responses of the orange-spotted grouper, Epinephelus coioides. Fish Shellfish Immunol 25(1-2):19-27.

ZAHAROFF DA, ROGERS CJ, HANCE KW, SCHLOM J, GREINER JW (2007) Chitosan solution enhances both humoral and cell-mediated immune responses to subcutaneous vaccination. Vaccine 25(11):2085-2094.

ZHENG FR, SUN XQ, LIU HZ, ZHANG JX (2006) Study on the distribution and expression of a DNA vaccine against lymphocystis disease virus in Japanese flounder (Paralichthys olivaceus). Aquaculture 261(4):1128-1134. 
